\title{
Viruses that Enhance the Aesthetics of Some Ornamental Plants: Beauty or Beast?
}

\author{
Rodrigo A. Valverde \\ Louisiana State University Agricultural Center, Baton Rouge, LA 70803 \\ Sead Sabanadzovic \\ Mississippi State University, Mississippi State, MS 39762 \\ John Hammond \\ Floral and Nursery Plants Research Unit, USDA-ARS, U.S. National Arboretum, Beltsville, MD 20705
}

\begin{abstract}
Microbes including fungi, bacteria, and viruses commonly cause diseases in humans, animals, and plants. Nevertheless, there are many beneficial microbes. The intestinal bacteria in humans and animals that contribute to food processing, the yeast used to produce bread, beer, wines, and cheeses, and the production of pharmaceuticals such as penicillin from fungi are among them. In the case of plants, there are several examples of microorganisms beneficial not only to the plants themselves but indirectly to humans as well. Some microbes can enhance plant health (77). Although there are many plant diseases caused by fungi, there are a number of fungi that can establish a symbiotic interaction with the host that is mutually beneficial to both. Some species of mycorrhizae are involved in nutrient absorption; other soil inhabitants such as Trichoderma spp. can protect plants against disease-causing fungi. Endosymbiotic fungi that increase plant growth are found associated with many plant species. Rhizobium leguminosarum, a bacterium involved in nitrogen fixation, is another microorganism beneficial to plants. Recently, researchers proved that a phytoplasma is the biological agent causing free-branching in poinsettias which is an economically beneficial trait for their producers (45). Beneficial viruses for plants have been discovered as well (52).
\end{abstract}

Plant viruses are biological entities consisting of RNA or DNA and, in most cases, a coat protein. Transmission through vectors, vegetative propagation, or seed is the main form of dissemination, although in some cases viruses are transmitted through mechanical contact. In general, viruses of plants have been studied primarily because they cause disease and economic losses in crops. Symptoms due to virus infections include foliar mosaic, mottle, ring spots, necrosis, malformation, curling/rolling, yellow vein, flower and/or foliage variegation, fruit malformations, and overall plant stunting. However, interactions between plant viruses and their hosts do not always result in disease. In recent years, there have been reports of many viruses infecting plants without causing disease. Examples of this are infections by dsRNA viruses of the

Corresponding author: Rodrigo A. Valverde, Department of Plant Pathology and Crop Physiology, Louisiana State University Agricultural Center, Baton Rouge, LA 70803; E-mail: rvalverde@ agcenter.lsu.edu

http://dx.doi.org/10.1094/PDIS-11-11-0928-FE

(C) 2012 The American Phytopathological Society families Partitiviridae and Endornaviridae. These viruses can replicate in the plant but have no detectable visual effect in the phenotype $(71,73,91)$. Moreover, there are some ssRNA viruses that cause only minor effects on the host, or the plant remains symptomless throughout most of the life cycle. Although, as pointed out earlier, most viruses that infect plants cause diseases that are detrimental to the plant, there are some instances in which infections by mild viral strains of a virus have been used to protect the plant against severe strains of the same virus $(19,98)$. There are other viruses that can cause desirable effects in their hosts, and infected plants have been selected or in some cases used by ornamental horticulturists to enhance their aesthetics. In most cases, this translates into an increase of their commercial value. There are several examples of ornamental plants being more marketable when infected by a particular virus than in the absence of the virus.

\section{Plants Desired by the Ornamental Plant Industry and Plant Enthusiasts}

Plants with unusual foliage and/or flowers are highly sought by horticulturists and many ornamental plant enthusiasts. Selections of many ornamental plants exhibiting green leaves with other colors such as white, yellow, or red, alone or combined (generally known as variegations) have been propagated and commercialized as distinct cultivars. Similarly, this practice has been conducted with flowers exhibiting desirable aesthetic value, usually in the form of flower breaking. Flower breaking describes the appearance of the flowers in which the petals, instead of being uniformly colored, are variegated due to the irregular distribution of pigments. Leaves can also exhibit vein discolorations that range from white to yellow. Most foliar or flower variegations and vein discolorations are the product of mutations that affect plastid development or transposable genetic elements that result in anomalous production of pigments $(43,48)$. Examples of genetic variegation are shown in Figure 1A and B. Plant viruses can cause symptoms that mimic genetic variegations and vein discolorations. Differentiation between genetic variegations and those caused by plant viruses is not an easy task, and it is often assumed that variegations are of a genetic nature. This illustrates, at least from the commercial point of view, the desirable effect of certain viral infections.

One of the first uses of aesthetic effects of plant viruses was the production and marketing of highly priced variegated tulips (Tulipa spp.; Liliaceae) by Dutch growers in the seventeenth century. The flower variegation, as we know now, is caused by the potyvirus 
Tulip breaking virus (17) and other potyviruses. Other well-known examples include the attractive mosaic patterns on the leaves of flowering maple (Abutilon pictum; Malvaceae) infected with Abutilon mosaic virus (41), the variegated flowers of camellia (Camellia japonica; Theaceae) infected with Camellia yellow mottle virus (66), and the yellow-veined Japanese honeysuckle (Lonicera japonica; Caprifoliaceae) infected with Honeysuckle yellow vein mosaic virus (63). In recent years, there have been other reports of plant viruses associated with unique phenotypes of ornamental plants, and some of them are being marketed as novel plant cultivars $(2,16,33,88,90,92 ; \mathrm{R}$. Valverde, unpublished). In this paper, we discuss some viruses that enhance natural beauty of certain ornamentals and increase their commercial value, and we discuss potential drawbacks and repercussions associated with their use.

\section{Plant Viruses Causing Aesthetic Effects}

A summary of the general properties of viruses documented to enhance the aesthetics of some ornamental plants are presented in Table 1.

Tulip breaking virus (TBV). For many years, it was thought that TBV was the earliest recorded plant virus. However, it is now generally accepted that the earliest written reference to a viruscaused symptom is described in a poem by the Japanese Empress Koken in AD 752. It is speculated that the yellow leaf symptoms
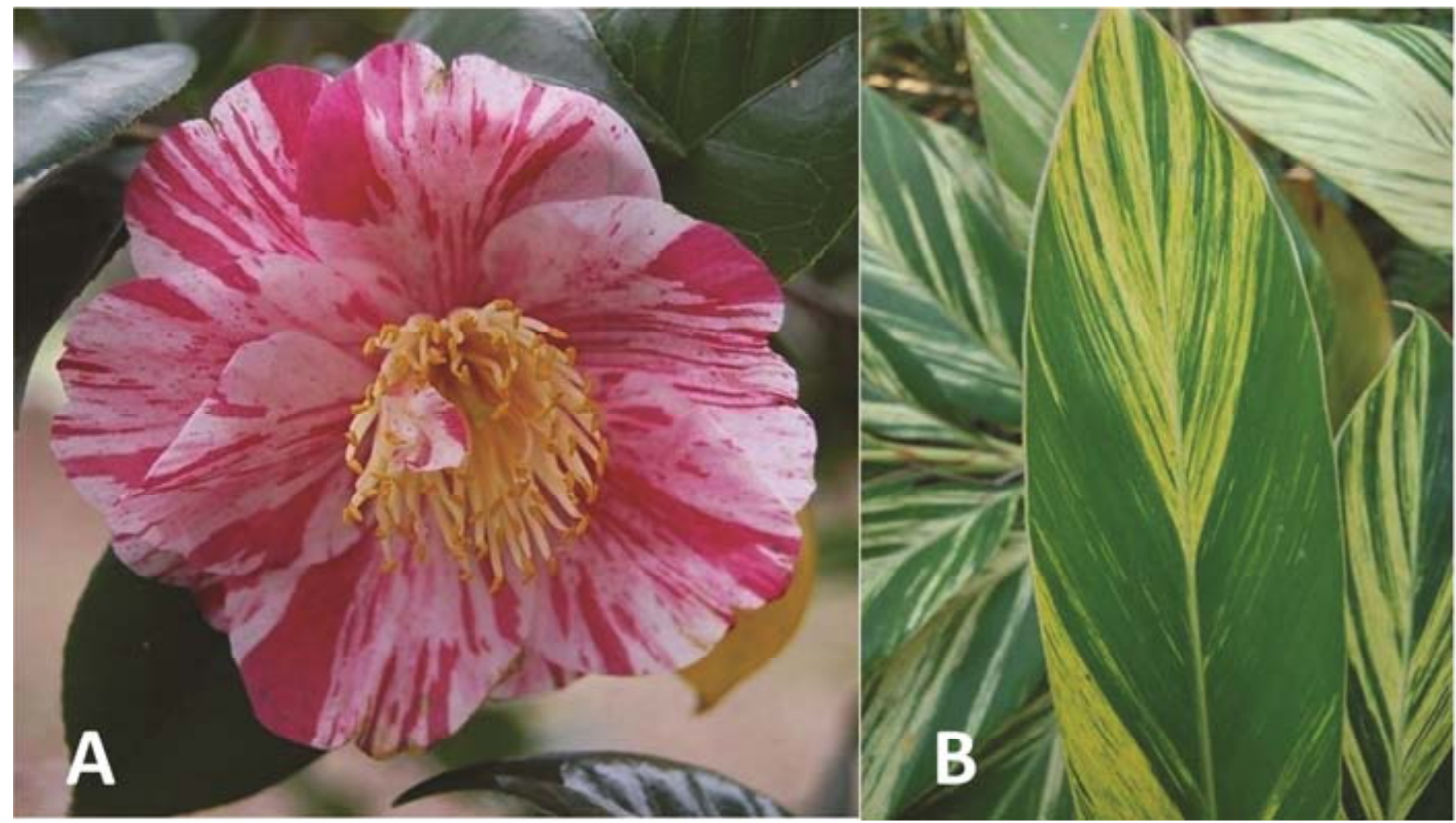

Fig. 1. Genetic variegations in A, Camellia japonica, and B, Alpinia zerumbet.

Table 1. List of selected viruses that enhance the aesthetics of some ornamental plants

\begin{tabular}{|c|c|c|c|c|c|c|}
\hline \multirow[b]{2}{*}{ Virus name } & \multirow[b]{2}{*}{ Genus } & \multicolumn{3}{|c|}{ Transmission } & \multirow[b]{2}{*}{ Susceptible hosts } & \multirow[b]{2}{*}{ References } \\
\hline & & $\mathbf{M}^{\mathbf{a}}$ & Vector & $\mathbf{S}^{\mathbf{b}}$ & & \\
\hline Abutilon mosaic virus & Begomovirus & Yes & Whiteflies $^{\mathrm{c}}$ & No & $\begin{array}{l}\text { Abutilon spp., Hibiscus spp., } \\
\text { Malva spp., Gossypium spp. }\end{array}$ & $37,41,58$ \\
\hline Camellia yellow mottle virus & Varicosavirus? & No & Fungi? & No & Camellia japonica, C. sasanqua & $\begin{array}{l}31,54,55,66 \\
67\end{array}$ \\
\hline $\begin{array}{l}\text { Clerodendron golden mosaic China } \\
\text { virus }\end{array}$ & Begomovirus & No & Whiteflies $^{c}$ & No & $\begin{array}{l}\text { Salvia splendens, Clerodendrum } \\
\text { cyrtophilum }\end{array}$ & 47,92 \\
\hline Cucumber mosaic virus & Cucumovirus & Yes & Aphids & Yes & $\begin{array}{l}\text { Solenostemon spp., Viola spp., } \\
\text { many wild and cultivated plants }\end{array}$ & 33,90 \\
\hline $\begin{array}{l}\text { Honeysuckle yellow vein mosaic virus, } \\
\text { Honeysuckle yellow vein virus }\end{array}$ & Begomovirus & No & Whiteflies $^{c}$ & No & $\begin{array}{l}\text { Lonicera spp., Solanum } \\
\text { lycopersicum, Nicotiana tabacum, } \\
\text { Capsicum аппиит }\end{array}$ & $44,61,63$ \\
\hline Nandina stem pitting virus & Capillovirus & No & ? & No & Nandina domestica & $2,96,99$ \\
\hline Pelargonium flower break virus & Carmovirus & Yes & $?$ & No & $\begin{array}{l}\text { Pelargonium peltatum, } \\
P . \times \text { hortorum }\end{array}$ & 12,16 \\
\hline Pseuderanthemum yellow vein virus & Begomovirus & ? & Whiteflies $^{c}$ & No & Pseuderanthemum sp. & 7,79 \\
\hline Tulip breaking virus & Potyvirus & Yes & Aphids & Yes & Tulipa spp., Lilium spp. & $17,23,65$ \\
\hline
\end{tabular}

${ }^{a}$ Mechanical transmission.

${ }^{\mathrm{b}}$ Seed transmission.

c Some isolates of these viruses were not whitefly transmissible. 
noted by the Empress more than a thousand years ago were likely caused by Eupatorium yellow vein virus (EpYVV), a begomovirus infecting Eupatorium makinoi which occurs naturally in Japan (75). Nevertheless, tulip breaking is one of the oldest virus diseases ever recorded. The symptoms were described in tulips by Carolus Clusius in 1576 (18). Today these plants with beautifully variegated flowers are referred to as "Rembrandt tulips" because they were a favorite subject in many paintings by the Dutch Masters. Although infected bulbs gradually degenerate, those producing variegated flowers were very desired and often sold for high prices, especially during the early seventeenth century. Tulips with variegated flowers were so rare and in such high demand that they created a wild speculation craze (tulipomania) which almost caused the collapse of the Dutch economy (21). TBV was deliberately transmitted by some growers by bulb grafting (11). While color variegation of tulips has been documented for several centuries, it was not identified as a virus disease until the early 1900s (17). TBV is a mechanically and aphid transmitted RNA virus with flexuous rod-shaped particles, belonging to the genus Potyvirus (65). Many common aphid species such as Myzus persicae and Aphis gossypii can transmit the virus in a nonpersistent manner to healthy plants. The symptoms on the tulip flowers consist of a blend of irregular flame or feather-like patterns which occur in red and yellow flowers (Fig. 2A). Other symptoms caused by the virus are foliar mottling and irregular production of flowers. Severe and mild strains of TBV have been reported (23). TBV-infected lilies (Lilium spp.) can react with leaf chlorosis and degeneration in addition to flower break. The concern about spread of this virus through infected tulips has lessened due to strict regulations on their importation. This measure, combined with reliable virus detection methods that include enzyme-linked immunosorbent assay and polymerase chain reaction have helped to manage this and other tulip viruses $(23,29)$. There are several related potyviruses causing symptoms similar to those of TBV reported to infect tulips $(23,29)$. Other viruses that infect tulips and reportedly could cause flower breaking include Arabis mosaic virus, Tobacco rattle virus, and Lily symptomless virus among others (4).

Although variegated flowers produced by tulips 1 or 2 years after becoming infected are beautiful, the vigor and flower quality of infected plants decline thereafter. Today, the virus is no longer used purposely to increase the aesthetics of the tulip flowers. Thanks to the efforts of Holland's professional breeders, tulips with the same exotic streaked coloration patterns are widely available. Though often sold as "Rembrandt" tulips, they are actually disease-free, genetically stable lookalikes. They are tulips of various other classifications, such as single late or lily-flowered, which have been bred to have Rembrandt-style colorations. Visibly TBVinfected plants of other varieties are removed from production fields following manual inspection, but some infected bulbs escape roguing, and TBV-induced variegation can still be occasionally found.

Abutilon mosaic virus (AbMV). Flowering maple (A. pictum), also called parlor maple or Indian mallow, is a shrub sold in the United States as an ornamental plant with the cultivar names 'Thompsonii' and 'Gold Dust'. This plant is native to Brazil but today is found naturalized throughout South and Central America. Flowering maple plants showing variegated foliage have been cultivated since the late 1800s (41). In 1869, Morren (58) was able to transmit the variegation by graft inoculations. Today we know that the variegation is caused by AbMV, a member of the genus Begomovirus. AbMV is a virus with a genome made of two molecules of circular single-stranded DNA, transmitted by the whitefly Bemisia tabaci and by mechanical inoculation (37). There are several reports of strains that are non-whitefly-transmissible $(7,22)$. The growth of flowering maples infected with AbMV does not seem to be adversely affected (60). In fact, the virus is responsible for most of the species ornamental value, and plant enthusiasts regard them as desirable for their variegated foliage (Fig. 3A); the mosaic develops as bright yellow or even white under high light conditions, or green-on-green under lower light conditions. This is a case of a plant disease in which infected plants are more desirable than uninfected plants. In the United States, the strain causing leaf variegation is not whitefly-transmitted and is transmitted mechanically with difficulty $(22,97)$. Nevertheless, strains of this virus from Brazil, where the plant originated, have been shown to be whitefly and mechanically transmitted (62). Some Abutilon species react to this virus with leaf crinkling, mottling, and mild chlorotic areas on leaves rather than the classic variegation (60). Experimentally, the virus has been shown to infect several species of the family Malvaceae including cotton.

Camellia yellow mottle virus (CYMoV). For many years, camellia breeders and hobbyists around the world have graft-transmitted a camellia virus $(\mathrm{CYMoV})$ that results in variegation of camellia flowers and occasional yellow mottle or ring spots on some leaves $(31,66,67)$ (Fig. 2B). This practice led to naming new virus-infected varieties. Camellia varieties with pink or red flowers exist in two forms, one with solid colored flowers and the other with variegated flowers. As in the case of variegated tulips, some cultivars with variegated flowers are of genetic origin (Fig. 1A) and others the result of $\mathrm{CYMoV}$ infections (Fig. 2B). Cultivars infected with CYMoV include 'Yuki-komachi', 'Elegance', and 'Aloha' (31). Despite being infected with the virus, some of


Fig. 2. A, Tulip infected with Tulip breaking virus; B, camellia infected with Camellia yellow mottle virus; and C, nandina 'Fire Power' showing virus symptoms. 
these plants have been growing and thriving for many years, and the variegation offers an interesting diversity. CYMoV has been known to occur in camellias since the late 1940s $(54,66)$; however, due to the lack of mechanical transmission, apparent narrow host range, and difficulty of purification, the current knowledge of this virus is still poor. Most of the studies conducted so far have dealt only with symptoms and the cytopathology of infected cells using the electron microscope $(27,31,55)$. Based on particle morphology and ultrastructure studies of infected cells, CYMoV has been proposed to be a tentative member of the genus Varicosavirus $(15,32)$ but is currently not recognized as such by the International Committee on Taxonomy of Viruses. Varicosaviruses consist of fragile, nonenveloped rods of about 320 to $360 \mathrm{~nm}$ in length with negative-sense ssRNA genome and are transmitted by the zoospores of the fungus Olpidium brassicae (15). Except for graft transmission (67), CYMoV has not been transmitted by other means. The host range of CYMoV seems to be restricted to Camellia spp.

Honeysuckle yellow vein mosaic virus (HYVMV) and Honeysuckle yellow vein virus (HYVV). Honeysuckle is a perennial herbaceous weed commonly found in Japan and Korea and often showing yellow vein diseases. Two distinct viruses have been isolated from Japanese honeysuckle showing yellow vein symptoms: HYVMV and HYVV. HYVMV causes yellowing of main and small veins followed by mosaic pattern, and HYVV causes yellow net symptoms accompanied by small elliptical shaped enations on the underside of the leaves (61). Both viruses are members of the genus Begomovirus, have a monopartite DNA genome, and are transmitted in a persistent manner by $B$. tabaci, although a strain of HYVMV isolated in the United Kingdom was not whitefly transmitted. Betasatellites have been associated with both HYVMV (61) and HYVV (44). Recently, these viruses have been reported infecting tomato in Korea and Japan (42,93). Symptoms of HYVMV in tomato consist of leaf curling and yellowing and overall plant dwarfing. Another susceptible host is tobacco, which reacts with leaf curling symptoms. In the United States, Japanese honeysuckle cultivars such as 'Gold Net' and 'Yellow Net' showing yellow vein are often found in catalogs of commercial plant companies (Fig. 3B). It is assumed that they are infected with HYVMV and/or HYVV.

Nandina stem pitting virus (NSPV) and other viruses of nandina. Heavenly bamboo, Nandina domestica (Berberidaceae), is a popular evergreen shrub native to eastern Asia. While the larger types, collectively referred to as common nandina (e.g., 'Gulf Stream'), are typically seed propagated, the dwarf cultivars, 'Fire Power', 'Harbor Dwarf', and 'Nana-purpurea', are vegetatively propagated. Several viruses have been reported associated with dwarf nandinas, including Cucumber mosaic virus (CMV) (6) and

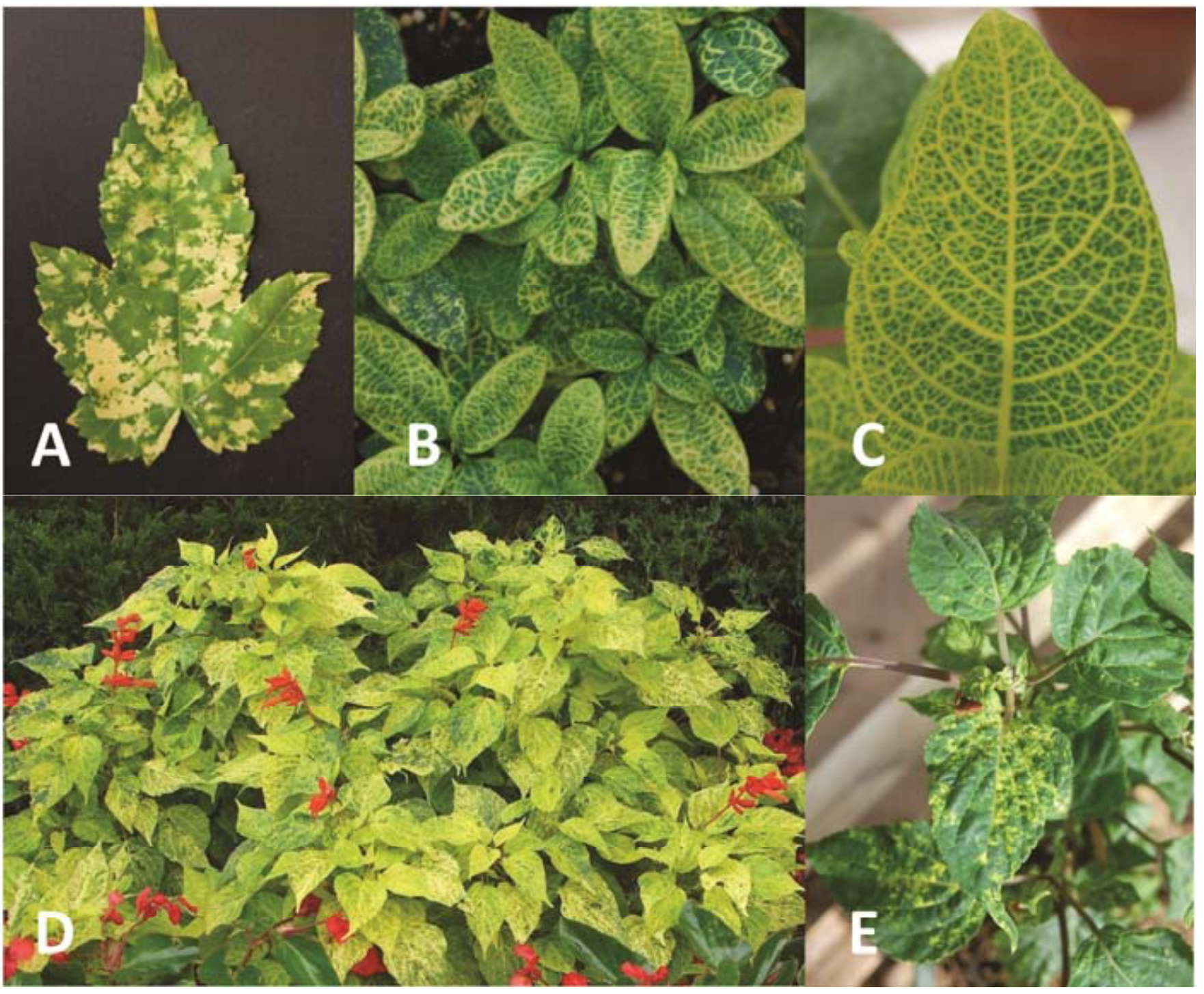

Fig. 3. Symptoms caused by begomoviruses: A, abutilon infected with Abutilon mosaic virus; B, honeysuckle 'Yellow Net' infected with a begomovirus; C, pseuderanthemum infected with a tentative begomovirus; D, Salvia splendens 'Dancing Flame' infected with Clerodendron golden mosaic China virus (CIGMCNV); and E, S. splendens 'Scarlet Sage' infected with CIGMCNV. 
Nandina mosaic virus $(35,82,99)$; Nandina mosaic virus is now recognized as a strain of Plantago asiatica mosaic virus (PIAMV) (35). In the early 1980s, 'Nana-purpurea' was found to be infected with an RNA virus named NSPV $(2,96)$. Plants infected with this virus exhibit reddish discoloration and irregular, inward curling of the leaves, stunting, and stem pitting. The virus is a tentative member of the genus Capillovirus and consists of flexuous rod-shaped particles ranging from 696 to $830 \mathrm{~nm}$ in length (modal length 755 $\mathrm{nm})$. NSPV can be transmitted by grafting. A vector of this virus has not been identified, and $N$. domestica is the only known host. Two other viruses have been isolated from dwarf nandina cultivars: (i) Apple stem grooving virus (Capillovirus) from plants showing leaf mosaic and rolling, and (ii) Alternanthera mosaic virus (AltMV) from plants showing chlorotic rings and leaf distortion (82). A correlation between the presence of CMV and PlAMV and the red foliage of 'Fire Power' has been observed (S. Scott, personal communication). AltMV alone is able to cause veinal reddening when inoculated to healthy seedlings of nandina (J. Hammond, unpublished). Since most of these viruses have been shown to coinfect the same plant, it is not unreasonable to speculate that the mixed virus infections are directly involved in the commercial attractiveness of these nandina genotypes (Fig. 2C). Nevertheless, this needs to be thoroughly investigated.

Cucumber mosaic virus (CMV). CMV is an RNA virus, a member of the genus Cucumovirus with spherical particles of about 30 $\mathrm{nm}$ in diameter, capable of infecting a wide range of plant species and having a worldwide distribution. This virus is transmitted in a nonpersistent manner by many aphid species including $M$. persicae and A. gossypii. CMV has been shown to cause flower variegation symptoms on wild violets (Viola spp., Violaceae) without causing foliar symptoms or apparent detriment to the plant (90) (Fig. 4A). The virus is widely distributed among wild violets in the Ozark Mountains of Arkansas where the unusual variegated flowers add diversity to the spring flowering season. CMV has also been reported to be common among clonally propagated coleus, Solenostemon scutellarioides (Lamiaceae), cultivars throughout the United States (33). A strain of this virus was shown to cause a unique and attractive yellow mosaic and oak-leaf line patterns on the red foliage of coleus 'Alabama' without causing any obvious effect on plant vigor (Fig. 4B). Although 'Alabama' is not negatively affected by CMV, mechanical inoculation of this CMV isolate to other coleus cultivars resulted in stunting, mosaic, and over-


Fig. 4. A, Viola sp. infected with Cucumber mosaic virus (CMV); B, coleus infected with CMV; C, ivy-leaf geranium infected with Pelargonium flower break virus; D, Angelonia sp. infected with Angelonia flower break virus; and E, New Guinea impatiens infected with Impatiens flower break virus. 
all unfitness of the plants (33). CMV also infects many other ornamentals, frequently causing flower breaks which may either enhance or detract from the aesthetic qualities of the flower, depending in part on the flower color. Even attractive floral effects must be weighed against the foliar symptoms and decline in productivity that often occur, such as the prominent yellow ring and line patterns that have been observed in leaves of Hippeastrum spp. (amaryllis) (24), or mosaic, foliar distortion and stunting, and flower break and malformation of lisianthus (49). CMV may also cause severe color break and deformation in gladiolus, in which four biologically distinct CMV isolates were identified among 100 plants of a single cultivar (80); CMV often occurs in gladiolus in mixed infection with Bean yellow mosaic virus (BYMV), causing more severe symptoms. In lilies, CMV alone causes vein-clearing and leaf curl, but it can cause severe necrosis in combination with Lily symptomless virus, which is also transmitted by aphids (25). Ranunculus infected with CMV often shows color break together with leaf crinkle or other deformations and dwarfing, which may be more severe in combination with any of several potyviruses (9). CMV is also an important pathogen in tomato and multiple other vegetable crops, and has a very wide host range, including species in at least 85 families.

Clerodendron golden mosaic China virus (ClGMCNV). 'Dancing Flame' is a popular salvia (Salvia splendens; Lamiaceae) cultivar with red flower spikes, described as having variegated foliage and currently being sold throughout the United States. It has been shown that the variegated foliage is of viral origin (92). The virus associated with 'Dancing Flame' is a strain of the putative begomovirus, ClGMCNV, which has been reported infecting clerodendron (Clerodendrum cyrtophyllum; Lamiaceae) in China (47). The symptoms caused by this virus on salvia include bright yellow mosaic, yellow vein, and mild leaf distortion (Fig. 3D). Although the ClGMCNV sequence places this virus in the Begomovirus genus, attempts to transmit the salvia isolate of ClGMCNV using B. tabaci biotype B were unsuccessful (92). It is possible that the salvia isolate has lost the capability of being transmitted by whiteflies after continued vegetative propagation as reported for some isolates of AbMV (97). In limited host range studies, ClGMCNV was able to infect three other cultivars of $S$. splendens by graft inoculations. The potential of this virus to infect other economically important plants should be further investigated, especially considering the fact that begomoviruses are highly prone to recombination. As in the case of abutilon infected with AbMV, and honeysuckle infected with HYVMV and/or HYVV, the infection of 'Dancing Flame' salvia by a begomovirus causes a unique foliage color and does not seem to be visibly detrimental to the plant. Therefore, it is another example of a "desirable plant disease".

Pseuderanthemum yellow vein virus (PYVV). PYVV is a tentative begomovirus infecting golden net bush (Pseuderanthemum carruthersii; Acanthaceae) (79). This plant native to Polynesia is popular in the United States, particularly in Hawaii and Puerto Rico, where it is used in hedges. An isolate of PYVV from Yemen was transmitted by graft inoculations and reported to be related to other begomoviruses by molecular hybridization; however, it was not transmitted by B. tabaci using colonies from diverse geographic locations (7). The virus causes a very attractive bright yellow coloration of the veins on the uppermost leaves, which sometimes become completely yellow (Fig. 3C). Lower/ older leaves tend to show less dramatic yellow vein symptoms. Not much is known on the biological or molecular properties of this virus, and studies on the host range of PYVV have not been conducted. Cultivated members of the family Acanthaceae include only ornamental plants.

Pelargonium flower break virus (PFBV) and Pelargonium net vein agent (PNVA). Geraniums (Pelargonium spp.; Geraniaceae), also called pelargoniums, are very popular flowering plants that can be grown as perennials or annuals. Ivy-leaf geraniums (P. peltatum) are often used in hanging baskets, while zonal geraniums $(P . \times$ hortorum $)$ are grown as garden and potted plants. Two types of virus-like symptoms are found in ivy-leaf geranium: yellow vein, also called net vein, and flower break. While flower break symptoms are ascribed to PFBV, the cause of the yellow vein is a graft-transmissible agent called PNVA, and it is assumed to be a virus (16). PFBV is an RNA virus in the genus Carmovirus (12). The virus can be easily transmitted by mechanical means, but a vector has not been reported. Ivy-leaf geraniums are symptomless, but many cultivars, particularly those with red flowers, show an attractive flower break symptom consisting of red petals with white streaks (Fig. 4C). Symptoms due to PFBV infections in zonal geraniums include white flower streaks, chlorotic spots on leaves, and stunting (12). The typical yellow vein symptom caused by PNVA can be found in the cultivar 'Crocodile' and several others. This symptom is more pronounced during cool weather (40). Like other "aesthetic viruses", PNVA does not appear to affect the growth and flowering of 'Crocodile' and 20 other infected geranium cultivars (16). PFBV and PNVA are commercially used in ivy-leaf cultivars to develop desired effects on the leaf or flowers. Mixed infections of PFBV and PNVA in ivy-leaf geraniums do not cause synergistic effects. Both agents can be eliminated through meristem culture. Information on properties and biology of PNVA is very limited. In contrast, there is plenty of information on PFBV, which is likely due to the serious disease that it causes on zonal geraniums. Therefore, there are efforts to eliminate this virus from propagation stock.

\section{Other Virus-Infected Ornamental Plants Showing Symptoms}

Ageratum yellow vein virus (AYVV) is widely distributed in a weedy species, Ageratum conyzoides (Asteraceae), throughout much of Asia, and is a monopartite begomovirus transmitted by whiteflies; the striking vein yellowing in the weed has been attributed to a combination of the begomovirus genome and a satellite DNA (74). The virus has not (to our knowledge) been reported in ornamental ageratum, and it would be unwise to deliberately introduce it, as AYVV causes a devastating disease in tomato (3).

Angelonia flower break virus (AnFBV) is a carmovirus first described from Angelonia spp. (Scrophulariaceae) in the United States (1), and separately reported as 'Angelonia flower mottle virus' from Germany (95). Foliar mottle is sometimes apparent, but the most prominent symptoms are spots of enhanced coloration in the flowers, with the spots often having a somewhat blistered appearance (raised or sunken relative to the surrounding tissue; Fig. 4D). AnFBV has also been reported in nemesia, verbena, and phlox $(5,53)$. Although some regard the flower break in angelonia as attractive, breeders and growers have attempted to eradicate the virus from their stocks. In hybrid phlox, mixed infections of AnFBV and either Alternanthera mosaic virus or Phlox virus $M$ result in significantly more severe symptoms and decline ( $\mathrm{J}$. Hammond, unpublished).

Cannas (Canna spp.; Cannaceae) are popular landscape plants grown worldwide. Cultivars such as 'Bengal Tiger', 'Pretoria', and 'Striped Beauty' show attractive yellow stripes on their foliage (Fig. 5A and B). Canna yellow mottle virus (CaYMV), a member of the genus Badnavirus, has been isolated from cultivars showing yellow stripes. However, the virus has also been detected and/or isolated from other canna cultivars showing foliar mottle and veinal necrosis (Fig. 5C) (50,94; S. Sabanadzovic, unpublished). CaYMV can affect plant vigor and can cause severe leaf necrosis. Additionally, there is evidence of the presence of several related viruses associated with these symptoms as well $(72 ; \mathrm{S}$. Sabanadzovic, unpublished). It has not been conclusively demonstrated that CaYMV is the causal agent of the attractive yellow stripes exhibited by the canna cultivars listed above. Other badnaviruses are known to integrate into the host genome, and CaYMV may also integrate into the canna genome; partial badnavirus sequences were identified from canna by deep sequencing (56). Two potyviruses, BYMV (13) and Canna yellow streak virus (CaYSV), have also been reported from canna. CaYSV has been associated with the speckling and streaking of multiple varieties of canna (56). 
Croton (Coidageum variegatum; Euphorbiaceae) is a common ornamental plant valued for the variation of leaf morphology and bright tones of color shown by many cultivars. Leaves can be green with yellow spots or completely yellow. Some cultivars have yellow veins (Fig. 6A) and/or spots that range from yellow to red. Although the color patterns on the leaves resemble symptoms caused by plant viruses, the general thought is that they are of genetic nature. A begomovirus, Croton yellow vein mosaic virus
(CYVMV), and a putative rhabdovirus have been isolated from plants showing the virus-like symptoms described above $(8,30,70)$ CYVMV was detected by molecular hybridization in several croton cultivars (30). The virus is transmitted by grafting and whiteflies (B. tabaci) to other croton plants and to several other plant species (30). Although excessive yellowing and poor growth is associated with CYVMV infection on croton, differentiation between genetically inherited color patterns from those caused by the
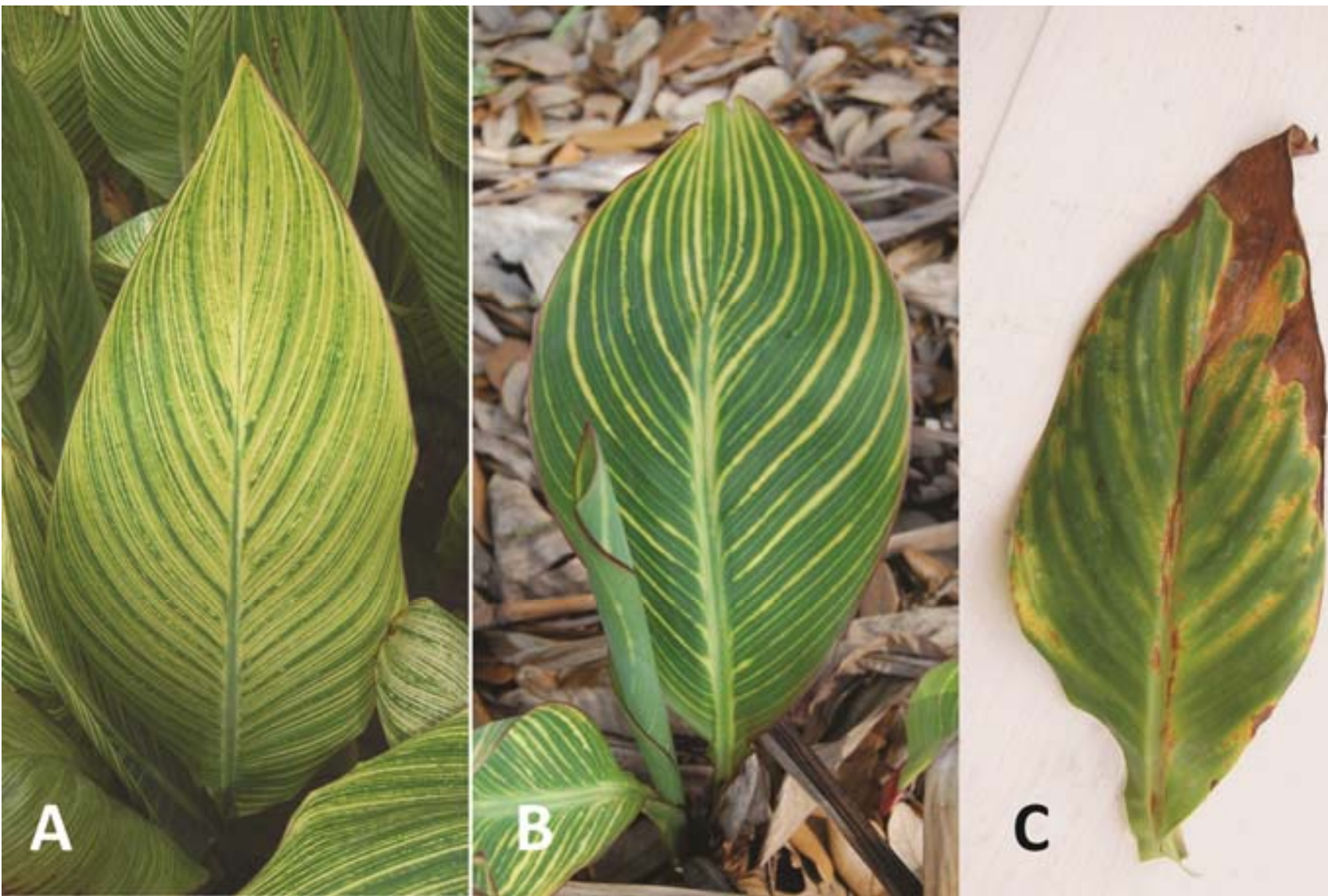

Fig. 5. Canna showing virus symptoms. A, 'Pretoria'; B, 'Bengal Tiger'; and C, canna infected with Canna yellow mottle virus.

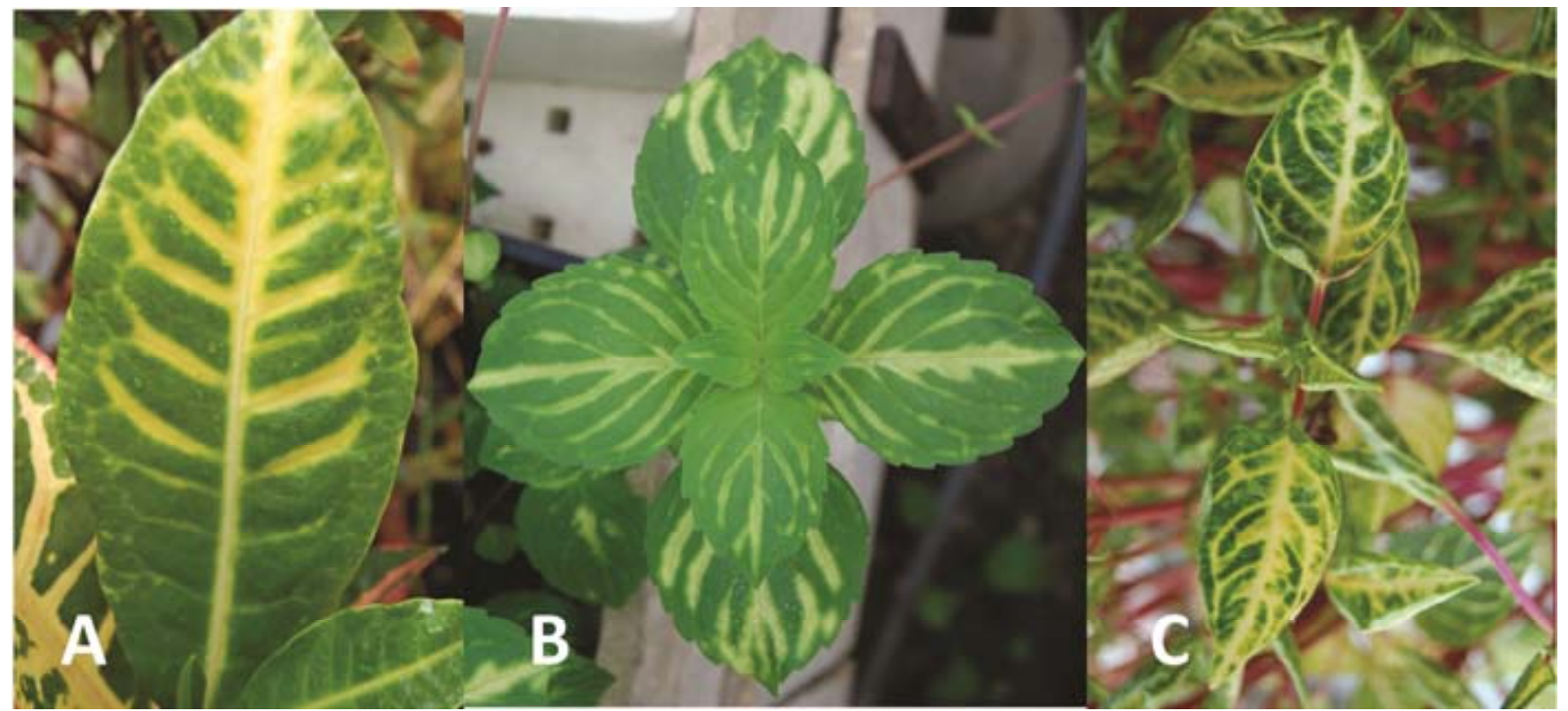

Fig. 6. Ornamental plants showing virus-like symptoms. A, Croton; B, mint 'Emerald Gold Mint'; and C, chicken gizzard plant. 
virus has not been well established $(70,81)$. The croton rhabdovirus caused dwarfing, vein yellowing, and leaf malformation on inoculated croton plants (8).

Dasheen mosaic virus (DsMV) is a potyvirus that occurs wherever aroids are grown commercially, and is transmitted by aphids. Before the advent of micropropagation, DsMV was almost ubiquitous in dieffenbachia, caladium, and calla lilies, but the incidence in tissue-culture-propagated plants has been significantly reduced in dieffenbachia and calla (100). The feathery mosaic and pigment variation observed in some aroids may enhance the visual appeal, but DsMV infection often has a significant effect on productivity. In dieffenbachia, DsMV infection symptoms vary from slight mosaic to ring spots to severe leaf distortion, and may vary significantly on leaves produced at different times of the year; symptoms in caladium are less obvious, whereas symptoms in calla frequently include conspicuous distortion (99). DsMV has also been isolated from a terrestrial orchid, Spiranthes cernua, with foliar chlorotic blotching or mosaic (38).

Impatiens flower break virus (IFBV) was first isolated from a New Guinea impatiens cultivar apparently selected for its streaky flower patterning, and was identified as a novel potyvirus (39). No other hosts have been identified, although the virus is transmissible to other New Guinea impatiens cultivars, inducing a similar flower break but negligible foliar symptoms; IFBV was not transmissible to other types of impatiens (R. Jordan, personal communication; Fig. 3E). Whereas some potyviruses such as BYMV and Turnip mosaic virus (TuMV) have very wide host ranges, narrow host range potyviruses include a number of species that infect various ornamentals (34).

Mint (Mentha $\times$ gracilis; Lamiaceae) 'Golden Ginger Mint' and 'Emerald Mint' exhibiting yellow mottle on green leaves (Fig. 6B) are very attractive cultivars available through nursery catalogs and at garden centers across the United States. Tucker and Fairbrothers (83) reported that the foliar symptoms were caused by a virus. Postman et al. (69) identified the virus as Strawberry latent ringspot virus (SLRSV). However, further testing of other mint clones with these symptoms revealed that they were free of SLRSV but infected with Mint virus $X(86,88)$. SLRSV infects strawberries (Fragaria $\times$ ananassa; Rosaceae) and consists of spherical particles with an RNA genome and is transmitted by nematodes of the genus Xiphinema. The symptoms on strawberry plants are not known because original sources collected from production fields were also infected with other viruses. This virus infects strawberry in California in the United States and in British Columbia, Canada. SLRSV in mixed infections with other viruses can dramatically decrease strawberry yields and has a wide host range that exceeds 125 plant species. This virus has only been found on mint and strawberries in the United States; however, it can infect many broadleaf crops. Several other viruses have been isolated from 'Golden Ginger Mint'. They include two closteroviruses, a vitivirus, and a potexvirus (see Tzanetakis et al., 2010, for descriptions of these viruses in mint) (85-88). It is not clear whether only SLRSV alone or other viruses are required for mint to express yellow mottle. SLRSV also infects other ornamentals including gladiolus (80), lilies (25), narcissus (14), phlox (28), and roses, in which infection may cause scion bud death (51).

Narcissus mosaic virus (NMV) has been reported to infect daffodil (Narcissus pseudonarcissus; Liliaceae), one of the most popular ornamentals. Reverse bicolor daffodil flowers display yellow flowers with patches of white but do not show foliar symptoms. The potexvirus NMV has been shown to be the cause of the color break of bicolor daffodil flowers (36). Several other viruses cause significant symptoms in daffodils (14).

Chicken gizzard plant (Iresine herbstii; Amaranthaceae) 'Aureo-reticulata' (Fig. 6C) and several coleus cultivars commercially available from many nurseries in the United States often show virus-like symptoms consisting of mosaic, mottle, veins of various colors, and leaf distortions. Several viroids have been isolated from these plants, but have not been associated with symptoms $(26,78)$.
Potential Problems with the Commercialization

\section{of Virus-Infected Ornamental Plants}

Although the enhanced aesthetic value of some ornamental plants is considered an example of a beneficial consequence of virus infections, most virus-infected plants do not fare well. Some of the viruses associated with desirable effects in ornamental plants include virus species that are capable of causing disease in economically important crops, including other ornamental plants. Even viruses that are usually symptomless in their original host may cause severe symptoms in another; for example, Lily symptomless virus is often symptomless in Lilium species (25), but may cause dramatic curling, chlorotic striping, and yellowing in spider lily (Hymenocallis littoralis) as well as in some lily cultivars (76), and more severe symptoms in combination with CMV or Lily mottle virus (25). A virus symptomless or aesthetically pleasing in some ornamental plants, but causing severe disease in other ornamentals or agronomic crops, could be extremely damaging. The expansion of the geographic distribution of these infected plants, the increasing evidence of genetic recombination among viruses, and the worldwide distribution of many of their vectors constitute a potential for disease outbreaks.

\section{Begomoviruses}

Viruses that cause bright yellow foliar symptoms on their hosts, many of them begomoviruses, appear to be the most common ones selected to enhance the aesthetics of ornamental plants. Begomoviruses are a rapidly evolving group of whitefly-transmitted viruses (7). The expansion of the geographical distribution of B. tabaci, the vector of begomoviruses, together with the emergence and spread of new biotypes, increase the chance of the introduction of these viruses to new areas and therefore infections of new crops (59).

There are many reports of viruses belonging to this genus causing losses to many major crops throughout the world. They include serious disease outbreaks in vegetable crops such as pepper, cucurbits, and tomato.

Diseases caused by the begomovirus Tomato yellow leaf curl virus (TYLCV) and its many strains are one of the main limiting factors for tomato production in the tropical and subtropical areas of the world (57). The introduction of TYLCV-Israel in the United States, likely in infected plants, illustrates the potential problem of having virus-infected plants (68). In this case, infected tomato transplants were rapidly distributed via retail garden centers throughout Florida, and infected plants purchased by homeowners appeared to be the source of the virus for nearby commercial nurseries and production fields. The virus quickly spread to nearby states, mostly through infected transplants. It is clear that the movement of infected plants played a role in the spread of this virus. TYLCV has also been reported from lisianthus (49), which could serve as a means of introduction of the virus to a tomatogrowing region.

It is widely accepted that recombination plays an important role in the evolution and genetic diversity of begomoviruses. Mixed infections leading to new begomovirus species in nature has been demonstrated $(7,57)$. Molecular analyses of the sequences of some newly described begomoviruses have revealed in numerous cases that they are the product of recombination $(42,59)$. Extensive recombination events among two closely related honeysuckle viruses (HYVMV and HYVV), Tobacco leaf curl Japan virus, and EpYVV have been reported $(42,64,89)$. Recent reports of recombinant forms of HYVMV and HYVV in Japan and Korea causing yellow dwarf disease of tomato should be of concern $(42,93)$. It is postulated that HYVMV was transmitted to tomato from honeysuckle by B. tabaci. The presence of betasatellite together with HYVMV caused more severe stunting symptoms in tomato plants (61). This is another example of a virus that enhances the aesthetic of an ornamental plant but causes disease in an economically important crop. The spread of these viruses to an unrelated plant species demonstrates the potential of these viruses to increase their host range. 
Similar to flowering maple infected with AbMV, the infection of salvia 'Dancing Flame' with a strain of ClGMCNV seems to be commercially attractive, as it enhances the natural beauty of this plant. AbMV has negligible effects on plant growth, vigor, and flowering (60), which also seems to be the case with the ClGMCNV infection of 'Dancing Flame'; however, graft inoculations of other $S$. splendens cultivars resulted in foliar variegation, stunting, and flower spike malformations (Fig. 4E), indicating that this virus causes undesirable symptoms in those cultivars. The potential of this virus to infect other economically important plants should be further investigated.

There are reports of strains of AbMV and HYVMV being transmitted by B. tabaci $(62,63)$. However, nontransmissible strains of these viruses have also been reported $(7,22,97)$. In a study conducted in the United Kingdom (7), isolates of three viruses infecting ornamental plants grown specifically for their virus-caused foliar patterns (AbMV, HYVMV, and PYVV) were not transmitted by colonies of $B$. tabaci from the Americas, Africa, Asia, and the Middle East. Similarly, transmission attempts of ClGMCNV with B. tabaci biotype B failed (92). The lack of transmissibility of these begomoviruses could be the result of continuous clonal propagation of the infected plants that leads to changes in the coat protein sequence/conformation, which is involved in whitefly transmission (97). Although some of these begomoviruses and/or some strains infecting ornamental plants are not transmitted by vectors, transmissible strains can develop through various mechanisms.

\section{Hosta virus X (HVX) a Case Study of an Ornamental Virus}

Hostas (Hosta spp.; Liliaceae) are shade tolerant plants that have become popular for their foliage and flowers. A virus identified as HVX and found to be widespread among hosta cultivars in the north central United States has had a negative impact in the hosta industry $(20,46)$. HVX is a member of the genus Potexvirus, transmitted mechanically by wounding and by vegetative propagation, and can cause severe diseases on susceptible hosta genotypes $(10,20,64)$. Symptoms consist of foliar chlorotic mottling, distortion, necrosis, mosaic, ring spots, and discolorations along or between the veins. In many cases, differentiation of symptoms from normal genetic discolorations, which are common in hostas, is not easy. After the discovery of the virus in several hosta cultivars in Minnesota, it was found in many other cultivars throughout the United States $(10,20)$. At the same time, some hosta growers began finding what appeared to be new, interesting sports which consisted of plants showing various types of foliar variegation. Later it was determined that the foliar variegations were caused by HVX. However, by that time, some professionals and amateur horticulturists had named the HVX-infected hostas and offered them as new cultivars.

The diversity of foliar patterns caused by this virus may have caused the propagation of new virus-infected cultivars by these hosta enthusiasts, and this could have contributed to the unintentional spread and epidemics of the virus. There have been great efforts by the hosta industry and researchers to educate the public and hopefully manage the disease. This has led to the development of reliable serological testing methods for the virus and recommendations such as the purchase of virus-free plants and the destruction of any infected plants. The HVX epidemic in the United States is an example of the dangers of ornamental viruses that cause desired aesthetic effects in plants.

\section{Conclusions}

Although the interactions between some of the viruses and their ornamental hosts described here do not appear to harm the host plant, the deliberate utilization of plant viruses to enhance the aesthetics of ornamental plants can lead to potential problems. Some of these viruses are pathogenic to other crops or have the potential to be pathogenic through mutations or recombination. Some of the viruses described here have been used for many years to produce unique ornamental plants without detrimental effects. CYMoV does not appear to significantly affect the vigor or flowering of camellia, although camellia growers recognize that some of the plants that display variegation (presumably CYMoV-infected) grow more slowly than other cultivars, and some have observed that flowers are smaller on "virus-infected" plants of a cultivar. Virus symptoms on the foliage are rare and seasonal. A yearly fluctuation of the extent of variegation has been reported (31). There have not been any reports of natural transmission of this virus. Although the virus putatively belongs to a genus that includes viruses transmitted by the fungus $O$. brassicae, CYMoV-free camellia cultivars grown near virus-infected camellias for more than 20 years in several locations in Louisiana have not shown any evidence of infection by this virus (R. Valverde, unpublished).

NSPV affects the leaf shape, color, and vigor of $N$. domestica, which can be a desired character. The virus does not have any known vector, and the only identified host is nandina. Therefore, like CYMoV, NSPV may be an ideal aesthetic virus. However, recent reports suggest that other viruses, known to be pathogenic in other hosts, are also associated with the desired nandina growth and foliage characteristics $(35,82)$. As in the case of nandina, yellow stripes on the leaves of some canna cultivars may be caused by more than one virus (see above). Furthermore, limited research on the biology of ClGMCNV and PYVV has been conducted which questions the deliberate propagation of infected plants. These viruses cause an attractive and desired yellowing of the leaves. The strains of these viruses infecting salvia and golden net bush studied so far are not transmitted by B. tabaci $(7,92)$.

As pointed out earlier, one of the potential problems of "using" plant viruses to increase aesthetics of ornamental plants is that pathogenic strains could develop. Moreover, if transmitted, these viruses can not only cause disease but could interact with other plant viruses as well as with indigenous plant species, or recombine with related viruses to form new and more destructive types. Since there are many viruses that are endemic in clonally propagated ornamental plants, some of them symptomless, additional viral infections may result in synergistic effects resulting in severe diseases. Plants with a virus infection can also be more susceptible to other pathogens than are healthy plants.

The ability of these viruses to cause unique foliar or flower color patterns in plants attracts collectors of many botanic gardens throughout the world, and therefore they are widely distributed. Based on the information presented here, care should be taken to avoid further spread and introduction of these viruses to new geographical locations where susceptible crops or efficient vectors may already be present. In-depth studies on the molecular and biological properties of these viruses must be conducted before commercializing their use. This should include inoculating other plant species, particularly economically important crops, and conducting transmission experiments with vectors. It should be noted that once a virus becomes established in a vegetatively propagated ornamental crop, it is difficult, time-consuming, and potentially expensive to eradicate the virus and to re-establish healthy clones of the desirable variety. Tulips and other bulb crops are prime examples where the tissue culture required to obtain virus-free material, and subsequent multiplication to commercial production levels, may take years. The rapid propagation and distribution of virus-infected orchid clones has resulted in wider distribution of several viruses, leading to their further spread within many orchid collections. Where variegations are aesthetically desirable, selection of genetically based rather than virus-caused variegation is a preferable option; for example, there are now a number of tulip cultivars having the Rembrandt-type floral patterning as a result of genetic rather than virus-caused flower break.

Certain viruses that may confer aesthetic benefits in one host may cause an unattractive disease or cause significant losses in another host; it would be unwise to deliberately transfer such viruses to other varieties of the "beneficial" host and thus increase the risk of spread to additional ornamental species and agronomic 
crops. The safest viruses to consider for broader applications to boost ornamental qualities are those which are already widely established within the industry, and which have very narrow host ranges (such as CYMoV, IFBV, and NSPV), and those which have lost the ability to be transmitted by vectors but can be transmitted by grafting or pollen (such as AbMV) in species that are normally propagated vegetatively. Viruses such as AYVV, which is known to produce an attractive phenotype in ageratum (albeit a weedy rather than an ornamental species), but which also is known to cause a devastating disease in tomato, and is also readily transmissible by whiteflies, should not be considered for application in ornamentals unless a mutant form unlikely to regain vector competency can be produced (as has apparently occurred naturally with AbMV and possibly ClGMCNV). Wide-host-range viruses, and especially those transmitted by thrips and whitefly, the most problematic virus vectors to control in greenhouses, should not be considered no matter how aesthetically pleasing an infection in one host might be. Impatiens necrotic spot virus and Tomato spotted wilt virus (thrips-transmitted tospoviruses) and TYLCV (whitefly transmitted begomovirus) are examples that are already known to have detrimental effects in a large number of crop species, including ornamentals; fortunately, such destructive viruses do not generally present an aesthetic phenotype that would encourage deliberate propagation of infected plants. The aphid-transmitted CMV should also be considered among the wide-host-range viruses to avoid, despite the aesthetic considerations of infected wild violets and coleus.

For many viruses affecting ornamentals, too little is known regarding host range among either ornamentals or agronomic crops to allow recommendations regarding possible aesthetic value. Among some crops, there may be alternative viruses that might be considered, where a related virus might produce similar symptoms but have a much more restricted host range. For example, at least six potyviruses affect ranunculus, including Potato virus $Y$ (PVY) and TuMV (84), which both have wide host ranges. Four newly described viruses produce somewhat similar symptoms to PVY and TuMV, but appear to have much narrower host ranges (84) as is common among potyviruses (34). If the symptoms in ranunculus were deemed aesthetically desirable, one of the narrow-host-range viruses would be a far better choice than either PVY or TuMV.

It is difficult to predict whether or not the "aesthetic viruses" listed here which are not currently known to infect agronomic crops could spread to such crops and cause an epidemic and/or disease in the future. In addition to the possibility of disease in other crops, a preinfection of an ornamental with an aesthetic virus may render the host more susceptible to infection by a second, less benign virus, and possible synergistic reactions. In the case of deliberately produced and distributed virus-infected ornamentals, perhaps the old warning "Caveat emptor" (Let the buyer beware) should be substituted with "Caveat venditor" (Let the seller beware), as there may be liability issues in the event of transmission to other crops. Because of the current unrestricted commercial trade and sales of some of these plants, it is likely that all the viruses described above are widespread in the United States and other countries. Due to the potential problem that some of these viruses can cause to agriculture, there is a need to limit the importation of infected plants, and to screen for the presence of viruses currently not known within the United States. Therefore, regulatory procedures will have to be implemented with some of these viruses to minimize their dissemination.

\section{Literature Cited}

1. Adkins, S., Hammond, J., Gera, A., Maroon-Lango, C. J., Sobolev, I., Harness, A., Zeidan, M., and Spiegel, S. 2006. Biological and molecular characterization of a novel carmovirus isolated from Angelonia. Phytopathology 96:460-467.

2. Ahmed, N. I., Christie, S. R., and Zettler, F. W. 1983. Identification and partial characterization of a closterovirus infecting Nandina domestica.
Phytopathology 73:470-475.

3. Andou, T., Yamaguchi, A., Kawano, S., Kawabe, K., Ueda, S., and Onuki, M. 2010. Ageratum yellow vein virus isolated from tomato plants with leaf curl on Ishigaki Island, Okinawa, Japan. J. Gen. Plant Pathol. 76:287-291.

4. Asjes, C. J. 1992. Viruses in tulips in the Netherlands. Acta Hortic. 377:289-300.

5. Assis Filho, F. M., Harness, A., Tiffany, M., Gera, A., Spiegel, S., and Adkins, S. 2006. Natural infection of verbena and phlox by a recently described member of the Carmovirus genus. Plant Dis. 90:1115.

6. Barnett, O. W., and Baxter L. W. 1973. Cucumber mosaic virus on Nandina domestica in South Carolina. Plant Dis. Rep. 57:917-920.

7. Bedford, I. D., Briddon, R. W., Brown, J. K., Rosell, R. C. and Markham, P. G. 1994. Geminivirus transmission and biological characterisation of Bemisia tabaci (Gennandius) biotypes from different geographical regions. Ann. Appl. Biol. 125:311-325.

8. Bellardi, M. G. 1991. First report of rhabdovirus-like particles in croton (Codiaeum variegatum). Plant Dis. 75:862.

9. Bertaccini, A., and Bellardi, M. G. 1995. Ranunculus. Chapter 32, pages 346-351 in: Virus and Virus-like Diseases of Bulb and Flower Crops. G. Loebenstein, R. H. Lawson, and A. A. Brunt, eds. John Wiley \& Sons/Balaban, Chichester, UK

10. Blanchette, B., and Lockhart, B. 2003. Hosta virus X: A three-year study Hosta J. 35:19-23.

11. Bos, L. 1995. Viruses of ornamentals: Historical perspectives. Chapter 2, pages 15-22 in: Virus and Virus-like Diseases of Bulb and Flower Crops. G. Loebenstein, R. H. Lawson, and A. A. Brunt, eds. John Wiley \& Sons/Balaban, Chichester, UK.

12. Bouwen, I. 1996. Pelargonium flower break carmovirus. Pages $932-935$ in: Viruses of Plants: Descriptions and Lists from the VIDE Database. A. Brunt, K. Crabtree, M. Dallwitz, A. Gibbs, and L. Watson, eds. CAB International, Cambridge, UK.

13. Brierley, P., and Smith, F. F. 1948. Canna mosaic in the United States. Phytopathology 38:230-234.

14. Brunt, A. A. 1995. Narcissus. Chapter 29, pages 322-334 in: Virus and Virus-like Diseases of Bulb and Flower Crops. G. Loebenstein, R. H. Lawson, and A. A. Brunt, eds. John Wiley \& Sons/Balaban, Chichester, UK.

15. Brunt, A. A., Milne, R. G., Sasaya, T., Verbeek, M., Vetten, H. J., and Walsh, I. A. 2005. Genus Varicosavirus. Pages 669-671 in: Virus Taxonomy: Eighth Report of the International Committee on Taxonomy of Viruses. C. M. Fauquet, M. A. Mayo, J. Maniloff, U. Desselberger, and L. A. Ball, eds. Elsevier Academic Press, London.

16. Cassells, A. C., Minas, G., and Bailiss, K. W. 1982. Pelargonium net vein agent and pelargonium petal break as beneficial infections of commercial pelargoniums. Sci. Hortic. 17:89-96.

17. Cayley, D. M. 1928. "Breaking" in tulips. Ann. Appl. Biol. 15:529-539.

18. Clusius, C. 1576. Rariorum aliquot stirpium per Hispanias observatarum historia. Ex officina Christophori Plantini (publisher).

19. Costa, A. S., and Muller, G. W. 1980. Tristeza control by cross protection. Plant Dis. 64:538-541.

20. Currier, S., and Lockhart, B. E. L. 1996. Characterization of a Potexvirus infecting Hosta spp. Plant Dis. 80:1040-1043.

21. Dash, M. 1999. Tulipomania: The Story of the World's Most Coveted Flower \& the Extraordinary Passions It Aroused. Three Rivers Press, New York.

22. de Souza, V. B. V., and Kim, K. S. 1990. Cytopathology and transmission characteristics of a virus isolate from Abutilon striatum. Phytopathology 80:548-552.

23. Dekker, E. L., Derks, A. F. L. M., Asjes, C. J., Lemmers, M. E. C., Bol, J. F., and Langeveld, S. A. 1993. Characterization of potyviruses from tulip and lily which cause flower-breaking. J. Gen. Virol. 74:881-887.

24. Derks, A. F. L. M. 1995. Hippeastrum (amaryllis). Chapter 25, pages 293297 in: Virus and Virus-like Diseases of Bulb and Flower Crops. G. Loebenstein, R. H. Lawson, and A. A. Brunt, eds. John Wiley \& Sons/Balaban, Chichester, UK.

25. Derks, A. F. L. M. 1995. Lily. Chapter 28, pages 313-321 in: Virus and Virus-like Diseases of Bulb and Flower Crops. G. Loebenstein, R. H. Lawson, and A. A. Brunt, eds. John Wiley \& Sons/Balaban, Chichester, UK.

26. Fonseca, M. E. N., Boiteux, L. S., Singh, R. P., and Kitajima, E. W. 1989. A viroid from Coleus species. Plant Dis. 74:80.

27. Gailhofer, M., Thaler, I., and Milicic, D. 1988. Occurrence of camellia leaf yellow mottle virus (CLYMV) on East Adriatic coast. Acta Hortic. 234:385-391.

28. Gera, A., and Cohen, J. 1995. Phlox. Chapter 37, pages 421-425 in: Virus and Virus-like Diseases of Bulb and Flower Crops. G. Loebenstein, R. H. Lawson, and A. A. Brunt, eds. John Wiley \& Sons/Balaban, Chichester, UK

29. Hammond, J., and Chastagner, G. 1989. Field transmission of tulip breaking virus and serologically related potyviruses in tulip. Plant Dis. 73:331336.

30. Harrison, B. D., Muniyappa, V., Swanson, M. M., Roberts, I. M., and Robinson, D. J. 1991. Recognition and differentiation of seven whiteflytransmitted geminiviruses from India, and their relationship to African cassava mosaic and Thailand mung bean yellow mosaic viruses. Ann. Appl. Biol. 118:299-308. 
31. Hiruki, C. 1985. A preliminary study on infectious variegation of camellia. Acta Hortic. 164:55-62.

32. Hiruki, C. 1996. Camellia yellow mottle varicosavirus. Pages 285-286 in: Viruses of Plants: Descriptions and Lists from the VIDE Database. A. Brunt, K. Crabtree, M. Dallwitz, A. Gibbs, and L. Watson, eds. CAB International, Cambridge, UK

33. Holcomb, G. H., and Valverde, R. A. 1991. Identification of a virus causing mosaic in coleus. Plant Dis. 75:1183-1185.

34. Hollings, M., and Brunt, A. A. 1981. Potyviruses. Chapter 23, pages 731807 in: Handbook of Plant Virus Infections and Comparative Diagnosis. E. Kurstak, ed. Elsevier/North-Holland Biomedical Press, Amsterdam.

35. Hughes, P. L., Harper, F., Zimmerman, M. T., and Scott, S. W. 2005. Nandina mosaic virus is an isolate of Plantago asiatica mosaic virus. Eur. J. Plant Pathol. 113:309-313.

36. Hunter, D. A., Fletcher, J. D., Davs, M. K., and Zhang, H. 2011. Colour break in reverse bicolour daffodils is associated with the presence of Narcissus mosaic virus. Virol. J. 8:412.

37. Jeske, H., and Morales, J. F. 1996. Abutilon mosaic bigeminivirus. Pages 68-71 in: Viruses of Plants: Descriptions and Lists from the VIDE Database. A. Brunt, K. Crabtree, M. Dallwitz, A. Gibbs, and L. Watson, eds. CAB International, Cambridge, UK.

38. Jordan, R. L., Guaragna, M. A., Kinard, G., and Lynn, S. 2002. Detection and first report of Dasheen mosaic virus and a second potyvirus infecting the terrestrial orchid Spiranthes cernua. Acta Hortic. 568:253-260.

39. Jordan, R., Guaragna, M. A., and Putnam, M. 2011. Detection and molecular chacterization of new and emerging potyviruses or ornamental plants. Acta Hortic. 901:159-163.

40. Kemp, W. G. 1966. The occurrence of yellow-net vein virus in geraniums in Ontario. Can. Plant Dis. Surv. 46:81-82.

41. Keur, J. Y. 1934. Studies of the occurrence and transmission of virus diseases in the genus Abutilon. Bull. Torrey Bot. Club 61:53-70.

42. Kitamura, K., Ogawa, T., Sharma, P., and Ikegami, M. 2008. First report of Honeysuckle yellow vein mosaic virus on tomato affected by yellow dwarf disease in Japan. Plant Pathol. 57:391.

43. Lebowitz, R. J., and Kloth, R. H. 1986. Genetics of foliar variegation in coleus. J. Hered. 77:125-126.

44. Lee, G., Kim, S., Jung, J., Auh, C. K., Choi, E., Chang, M., and Lee, S. 2011. Agroinoculation of Nicotiana benthamiana with cloned Honeysuckle yellow vein virus isolated from Lonicera japonica. Arch. Virol. 156:785-791.

45. Lee, I.-M., Klopmeyer, M., Bartoszyk, I. M., Gundersen-Rindal, D. E., Chou, T.-S., Thomson, K. L., and Eisenreich, R. 1997. Phytoplasma induced free-branching in commercial poinsettia cultivars. Nature Biotech. 15:178-182.

46. Lewandowski, D. 2008. Hosta virus X. Fact Sheet. Agriculture and Natural Resources. The Ohio State University. HYG-3069-08. http://ohioline.osu. edu/hyg-fact/3000/pdf/3069.pdf

47. Li, J., and Zhou, X. 2010. Molecular characterization and experimental host-range of two begomoviruses infecting Clerodendrum cyrtophyllum in China. Virus Genes 41:250-259.

48. Lida, S., Morita, Y., Choi, J. D., Park, K. I., and Hoshino, A. 2004. Genetics and epigenetics in flower pigmentation associated with transposable elements in morning glories. Adv. Biophys. 38:148-159.

49. Lisa, V., and Gera, A. 1995. Lisianthus. Chapter 40, pages 443-448 in: Virus and Virus-like Diseases of Bulb and Flower Crops. G. Loebenstein, R. H. Lawson, and A. A. Brunt, eds. John Wiley \& Sons/Balaban, Chichester, UK.

50. Lockhart, B. E. L. 1988. Occurrence of Canna yellow mottle virus in North America. Acta Hortic. 234:69-72.

51. Loebenstein, G. 1995. Rose. Chapter 38, pages 426-437 in: Virus and Virus-like Diseases of Bulb and Flower Crops. G. Loebenstein, R. H. Lawson, and A. A. Brunt, eds. John Wiley \& Sons/Balaban, Chichester, UK.

52. Marquez, L. M., Redman, R., Rodríguez, R. J., and Roossinck, M. J. 2007. A virus in a fungus in a plant: Three-way symbiosis required for thermal tolerance. Science 315:513-515.

53. Mathews, D. M., and Dodds, J. A. 2008. First Report of Angelonia flower break virus in Nemesia spp. and other ornamental plants in California. Plant Dis. 92:651.

54. Milbrath, J. A., and McWhorter, F. P. 1946. Yellow mottle leaf, a virus disease of camellia. Am. Camellia Soc. Yearb. 51-53.

55. Miličić, D., Thaler, I., and Gailhofer, M. 1986. Infectious variegation virus of Camellia japonica L. in Yugoslavia. Acta Bot. Croat. 45:1-6.

56. Monger, W., Adams, I., Glover, R. H., and Barrett, B. 2010. The complete genome sequence of Canna yellow streak virus. Arch. Virol. 155:1515-1518.

57. Moriones, E., Navas-Castillo, J., and Díaz-Pendón, J. A. 2011. Emergence of begomovirus diseases. Pages 301-320 in: Recent Advances in Plant Virology. C. Caranta, M. A. Aranda, M. Tepfer, and J. J. Lopez-Moya, eds. Caister Acad., Norfolk, VA.

58. Morren, E. 1869. Contagion de la panachure. Bull. Acad. Roy. Belgique 28:434-442.

59. Navas-Castillo, J., Fiallo-Olive, E., and Sanchez-Campos, S. 2011. Emerging virus diseases transmitted by whiteflies. Annu. Rev. Phytopathol. 49:219-248

60. Nelson, S. C. 2008. Abutilon mosaic. University of Hawaii at Manoa, Col- lege of Tropical Agriculture and Human Resources, Cooperative Extension Service, PD-39. Retrieved September 5, 2011 from http://www.ctahr. hawaii.edu/oc/freepubs/pdf/PD-39.pdf.

61. Ogawa, T., Sharma, P., and Ikegami, M. 2008. The begomoviruses Honey suckle yellow vein mosaic virus and Tobacco leaf curl Japan virus with DNA $\beta$ satellites cause yellow dwarf disease of tomato. Virus Res. 137:235-244.

62. Orlando, A., and Silberschmidt, K. 1946. Estudos sobre a disseminacão natural do virus da clorose infecciosa das malvaceas (Abutilon virus 1 Baur) e a sua relacão com o inseto-vetor Bemisia tabaci (Genn.) (Homoptera: Aleyrodidae). Arq. Inst. Biol. São Paulo 17:1-36

63. Osaki, T., Kobatake, H., and Inouye, T. 1979. Yellow vein mosaic of honeysuckle (Lonicera japonica Thunb.), a disease caused by tobacco leaf curl virus in Japan. Ann. Phytopathol. Soc. Jpn. 45:62-69.

64. Park, M. H., and Ryu, K. H. 2003. Molecular evidence supporting the classification of Hosta virus $\mathrm{X}$ as a distinct species of the genus Potexvirus. Arch. Virol. 148:2039-2045.

65. Phillips, H. 1996. Tulip breaking potyvirus. Pages 1331-1333 in: Viruses of Plants: Descriptions and Lists from the VIDE Database. A. Brunt, K. Crabtree, M. Dallwitz, A. Gibbs, and L. Watson, eds. CAB International, Cambridge, UK

66. Plakidas, A. G. 1948. Possibility of utilizing virus infection as a means of producing new varieties of camellias. Am. Camellia Soc. Yearb. 107-109.

67. Plakidas, A. G. 1954. Transmission of leaf and flower variegation in camellias by grafting. Phytopathology 44:14-18.

68. Polston, J. E., McGovern, R. J., and Brown, L. G. 1999. Introduction of tomato yellow leaf curl virus in Florida and implications for the spread of this and other geminiviruses of tomato. Plant Dis. 83:984-988.

69. Postman, J. D., Tzanetakis, I. E., and Martin, R. R. 2004. First report of Strawberry latent ringspot virus in Mentha sp. from North America. Plant Dis. 88:907.

70. Raj, S. K., Srivastava, K. M., and Singh, B. 2006. Evidence from nucleic acid hybridization tests for geminivirus infection of ornamental crotons in India. Eur. J. Plant Pathol. 102:201-203.

71. Roossinck, M. J. 2011. The good viruses: Viral mutualistic symbioses. Nature Rev. Microbiol. 9:99-108.

72. Sabanadzovic, S., Abou Ghanem-Sabanadzovic, N., Ingram, D. M., and Lawrence, A. M. 2009. Hypervariability of badnavirus-like sequences in Canna indica L. (Abstr.) Phytopathology 99:S113.

73. Sabanadzovic, S., and Valverde, R. A. 2011. Properties of two cryptoviruses from pepper (Capsicum annuum). Virus Genes 43:307-312.

74. Saunders, K., Bedford, I. D., Briddon, R. W., Markham, P. G., Wong, S. M., and Stanley, J. 2000. A unique virus complex causes Ageratum yellow vein disease. Proc. Nat. Acad. Sci. 97:6890-6895.

75. Saunders, K., Bedford, I. D., Yahara, T., and Stanley, J. 2003. Aetiology: The earliest recorded plant virus disease. Nature 422:831.

76. Singh, A. K., Hallan, V., Verma, N., and Zaidi, A. A. 2004. Natural occurrence of Lily symptomless virus on spider lily. Plant Pathol. 54:255.

77. Smith, K., and Goodman. R. M. 1999. Host variation for interactions with beneficial plant-associated microbes. Annu. Rev. Phytopathol. 37:473-491.

78. Spieker, R. L. 1996. The molecular structure of Iresine viroid, a new viroid species from Iresine herbstii ('beefsteak plant'). J. Gen. Virol. 77:26312635.

79. Stanley, J., Bisaro, D. M., Briddon, R. W., Brown, J. K., Fauquet, C. M., Harrison, B. D., Rybicki, E. P., and Stenger, D. C. 2005. Family: Geminiviridae. Pages 301-326 in: Virus Taxonomy: Eighth Report of the International Committee on Taxonomy of Viruses. C. M. Fauquet, M. A. Mayo, J. Maniloff, U. Desselberger, and L. A. Ball, eds. Elsevier Academic Press, London.

80. Stein, A. 1995. Gladiolus. Chapter 24, pages 281-292 in: Virus and Viruslike Diseases of Bulb and Flower Crops. G. Loebenstein, R. H. Lawson, and A. A. Brunt, eds. John Wiley \& Sons/Balaban, Chichester, UK.

81. Swanson, M. M., Valand, G. B., Muniyappa, V., and Harrison, B. D. 1998 Serological detection and antigenic variation of two whitefly-transmitted geminiviruses: Tobacco leaf curl and croton yellow vein mosaic viruses. Ann. Appl. Biol. 132:427-435.

82. Tang, J., Olson, J. D., Ochoa-Corona, F. M., and Clover, G. R. G. 2010 Nandina domestica, a new host of Apple stem grooving virus and $\mathrm{Al}$ ternanthera mosaic virus. Aust. Plant Dis. Notes 5:25-27.

83. Tucker, A. O., and Fairbrothers, D. E. 1972. Mentha $\times$ gentilis L. 'Variegata': Nomenclature and viral origin. Taxon 21:209-210.

84. Turina, M., Ciuffo, M., Lenzi, R., Rostagno, L., Mela, L., Derin, E., and Palmano, S. 2006. Characterization of four viral species belonging to the family Potyviridae isolated from Ranunculus asiaticus. Phytopathology 96:560-566

85. Tzanetakis, I. E., Postman, J. D., and Martin, R. R. 2005. Characterization of a novel member of the family Closteroviridae from Mentha spp. Phytopathology 95:1043-1048.

86. Tzanetakis, I. E., Postman, J. D., and Martin, R. R. 2006. Mint virus X: A novel potexvirus associated with symptoms in 'Variegata' mint. Arch. Virol. 151:143-153.

87. Tzanetakis, I. E., Postman, J. D., and Martin, R. R. 2007. Identification, detection and transmission of a new Vitivirus from Mentha. Arch. Virol $152: 2027-2033$ 
88. Tzanetakis, I., Postman, J. D., Samad, A., and Martin, R. 2010. Mint viruses: Beauty, stealth, and disease. Plant Dis. 94:4-12.

89. Ueda, S., Onuki, M., Hanada, K., and Takanami, Y. 2008. Unique grouping of the Far East Asian begomovirus complex based on sequence analyses of the DNA-A genome and associated DNA beta satellite molecules isolated from tomato, honeysuckle and Eupatorium plants in Japan. Arch. Virol. 153:417-426.

90. Valverde, R. A. 1984. An unusual strain of cucumber mosaic virus causing flower breaking symptoms in wild violets. Plant Dis. 68:913-915.

91. Valverde, R. A., and Gutierrez, D. L. 2008. Molecular and biological properties of a putative partitivirus from Jalapeño pepper (Capsicum annuum L.). Mexican J. Phytopathol. (Rev. Mexicana Fitopatol.) 26:1-6.

92. Valverde, R. A., and Sabanadzovic, S. 2012. Detection and identification of Clerodendron golden mosaic China virus in Salvia splendens. Eur. J. Plant Pathol. Published Online First: 25 December 2011. DOI 10.1007/s10658011-9923-y

93. Wang, Y., Ji, J., Oh, T., Oh, S., Kim, S., Lee, H., Shim, M., Choi, C., Kim, S., Kim, I., and Kim, Y. 2011. Occurrence of Honeysuckle Yellow Vein Virus (HYVV) containing a monopartite DNA-A genome in Korea. Eur. J. Plant Pathol. 129:361-370.

94. Windham, A. 2008. First report of Canna yellow mottle virus in Tennessee.
Ornamental Pest and Disease Update. 2:3. http://soilplantandpest.utk. edu/publications/ornamentalnwsltr.html.

95. Winter, S., Hamacher, A., Engelmann, J., and Lesemann, D.-E. 2006. Angelonia flower mottle, a new disease of Angelonia angustifolia caused by a hitherto unknown carmovirus. Plant Pathol. 55:820.

96. Wisler, G. C., and Zettler, F. W. 1983. Three viruses of Nandina domestica: Nandina mosaic, nandina stem pitting, and cucumber mosaic. Plant Pathology Circ. No. 251. Fla. Dep. Agric. Consumer Serv.

97. Wu, Z. C., Hu, J. S., Polston, J. E., Ullman, D. E., and Hiebert, E. 1996. Complete nucleotide sequence of a nonvector-transmissible strain of Abutilon mosaic geminivirus in Hawaii. Phytopathology 86:608-613.

98. Yeh, S. D., Gonsalves, D., Wang, H. L., Namba, R., and Chiu, R. J. 1988. Control of papaya ringspot virus by cross protection. Plant Dis. 72:375380 .

99. Zettler, F. W., Abo El-Nil, M. M., Hiebert, E., Christie, R. G., and MacielZambolim, E. 1980. A potexvirus infecting Nandina domestica 'Harbor Dwarf'. Acta Hortic. 110:71-77.

100. Zettler, F. W., and Hartman, R. D. 1995. Chapter 44, pages 464-470 in: Virus and Virus-like Diseases of Bulb and Flower Crops. G. Loebenstein, R. H. Lawson, and A. A. Brunt, eds. John Wiley \& Sons/Balaban, Chichester, UK.

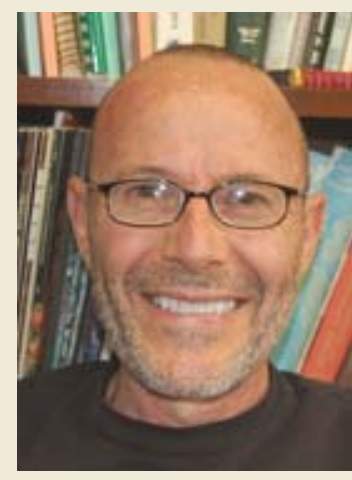

Rodrigo A. Valverde

Dr. Valverde is professor of plant pathology at the Louisiana State University Agricultural Center. He received the Ingeniero Agrónomo degree in 1978 from Universidad de Costa Rica and his Ph.D. in 1983 from the University of Arkansas. He conducted postdoctoral research on plant virology at the University of California at Riverside with Allan Dodds and at Davis with Bryce Falk. During 1987, he worked as a plant pathologist for Ball PanAm Plant Company in Florida. In 1988, he joined the Department of Plant Pathology and Crop Physiology of Louisiana State University. Dr. Valverde's plant virus research experience began in Costa Rica under the direction of Dr. Rodrigo Gamez. His current research interests are the detection and characterization of plant viruses with emphasis on dsRNA viruses.

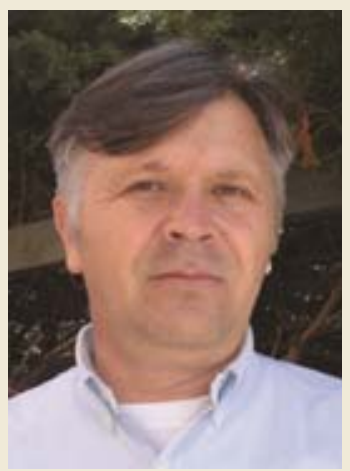

Sead Sabanadzovic

Dr. Sabanadzovic is an associate professor at the Department of Biochemistry, Molecular Biology, Entomology and Plant Pathology of Mississippi State University. He completed his B.S. degree in agriculture at the University of Sarajevo (Bosnia \& Herzegovina). He received his M.Sc. (1993) and Ph.D. (1997) degrees in plant virology from Mediterranean Agronomic Institute of Bari (MAIB, Italy) and the University of Bari (Italy) under the direction of G. P. Martelli and V. Savino. From 1997 to 2003, he worked at the Mediterranean Agronomic Institute of Bari, focusing on grapevine and olive viruses. In January 2003 he moved to the United States to work with J. K. Uyemoto and A. Rowhani on grapevine/fruit viruses at the Department of Plant Pathology of the University of California - Davis/Foundation Plant Services lab. In May 2004, he joined the faculty at Mississippi State University. His current research interests include viruses of blackberries and ornamentals, dsRNA viruses and the biodiversity/ecology of viruses in non-agronomic environments. $\mathrm{He}$ also teaches graduate and undergraduate courses at MSU.

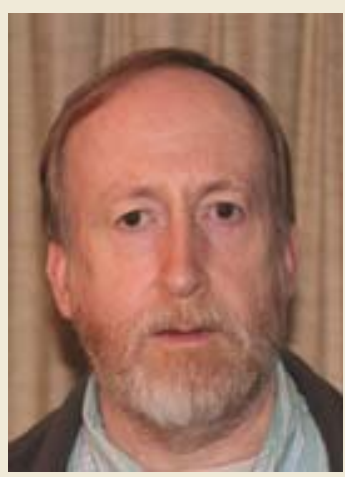

John Hammond

Dr. Hammond is a research plant pathologist with the Floral and Nursery Plants Research Unit of the USDA Agricultural Research Service in Beltsville, MD. He earned a B.Sc. in agricultural botany from the University of Reading, and a Ph.D. in plant virology from the University of East Anglia and the John Innes Institute, in the U.K. After moving to the United States for two years of postdoctoral research on Barley yellow dwarf virus at Purdue University, he moved to the USDA in Beltsville, where he has worked since 1982 on detection, identification, and characterization of viruses affecting ornamental plants. Working alone and in collaboration with others, he has identified and partially characterized several new viruses affecting various ornamentals, and developed reagents and protocols for detection and identification of these and other viruses infecting ornamentals. 